\section{Hip Fracture Management in an Orthogeriatric Clinical Care Center during the Covid-19 Pandemic in Bogotá, Colombia ${ }^{1}$}

\author{
Carlos Mario Olarte ${ }^{1,5 *}$, Ana Milena López ${ }^{2,5}$, Jonathan \\ Tihanyi Feldman ${ }^{3,5}$, Andrés Libos Zabala ${ }^{3,5}$, Diana Carolina \\ Morales $^{2,5}$, Aldo F Patiño ${ }^{4,5}$, Rodrigo F Pesantez ${ }^{1,5}$, Julián E \\ Salavarrieta ${ }^{4,5}$ and Valentina Sanint ${ }^{2,5}$ \\ ${ }^{1}$ Colegio Mayor de Nuestra Señora del Rosario, Bogotá, Colombia \\ ${ }^{2}$ Universidad de Caldas, Manizales, Colombia \\ ${ }^{3}$ Universidad de los Andes, Bogotá, Colombia \\ ${ }^{4}$ Universidad Nacional de Colombia, Bogotá, Colombia \\ ${ }^{5}$ Hospital Universitario Fundación Santa Fe de Bogotá, Bogotá, Colombia
}

\begin{abstract}
Objectives: This paper aims to compare treatment results on patients 65 years or older with hip fracture during the COVID-19 pandemic with previous treatment results in an Orthogeriatric Clinical Care Center.
\end{abstract}

Methods: A retrospective cohort's study was carried out in elder patients with hip fracture who had surgical management in Bogotá, Colombia before and during the COVID-19 pandemic.

Results: Patients admitted during the pandemic were more comorbid. The mean time between admission and surgery was less than 48 hours in both groups and there was no significant difference in in-hospital mortality, delirium, days of hospitalization, readmissions, nor in mortality after 30 and 90 days.

Discussion: Standardized orthogeriatric co-management during the COVID-19 pandemic maintained outcomes and results of quality

*Corresponding author: Carlos Mario Olarte, Colegio Mayor de Nuestra Señora del Rosario, Carrera 7 \#123-35, 10th floor Bogotá, Colombia; Tel: +57 315 8546947; E-mail: carlos.olarte@fsfb.org.co

Citation: Olarte CM, López AM, Feldman JT, Zabala AL, Morales DC, et al. (2021) Hip Fracture Management in an Orthogeriatric Clinical Care Center during the Covid-19 Pandemic in Bogotá, Colombia. J Gerontol Geriatr Med 7: 117.

Received: December 14, 2021; Accepted: December 23, 2021; Published: December 30, 2021

Copyright: ( 2021 Olarte CM, et al. This is an open-access article distributed under the terms of the Creative Commons Attribution License, which permits unrestricted use, distribution, and reproduction in any medium, provided the original author and source are credited.

${ }^{1}$ This research paper is the result of a study carried out in the Hospital Universitario Fundación Santa Fe de Bogotá, Colombia between August and October 2020. It had no funding resources and is affiliated to the Research Group of the Orthogeriatric Clinical Care Center of the FSFB University Hospital. indicators similar to those of pre-pandemic times, even though patients seen during the pandemic had a higher burden of comorbidity.

Keywords: COVID-19; Hip fracture; Orthogeriatric; SARS - CoV - 2

\section{Introduction}

From the report of the first cases of infection associated with the new coronavirus (COVID-19, also named as Severe Acute Respiratory Syndrome Coronavirus 2 [SARS-CoV-2]) in Wuhan, China in December 2019 [1], the cases of contagion by this pathogen spread rapidly nationwide and internationally, giving way to the global pandemic decreed by the World Health Organization (WHO) on March $11^{\text {th }}, 2020$ [1-3]. Currently all countries have a large number of infected people, which has become a major threat to health systems and each individual [4]. On March $6^{\text {th }} 2020$, the first case of a patient with COVID-19 infection was reported in Bogotá, Colombia, marking the end of the preparation phase and the beginning of the containment phase in the country [5].

The COVID-19 pandemic has had an important effect on the way in which health organizations provide medical care, focusing on the priority care of urgent pathologies that require immediate management to limit the spread of the disease. The orthopedic and traumatology services initially had to reorganize and cancel a large part of the elective surgeries to focus on those acute pathologies that require prompt attention [6]. With the increase of elderly population worldwide, fragility fractures -especially those of the hip (proximal femur)have become one of the most prevalent orthopedic pathologies in the emergency department, and despite the fact that orthopedic trauma decreased during confinement, hip fractures remain common in emergency departments [6]. The time between admission and surgery is an important factor to consider in these patients since performing surgery in the first 24 to 72 hours after admission is associated with a lower rate of mortality and certain postoperative complications [7].

Moreover, studies have shown that people with chronic health conditions such as cardiovascular disease, diabetes mellitus and obesity are more likely to become seriously ill from COVID-19, so the incidence of critical illness is higher among people over 65 years of age compared to the general population [8]. Thus, the high risk associated with contracting infection in this population together with the special considerations required in the treatment of hip fracture makes its management particularly challenging.

Several authors in different countries have described the experience of their respective orthopedic surgery departments regarding the management of elderly patients with hip fracture and the special measures taken in relation to COVID-19, and they coincide in certain aspects. First, as an initial screening for admissions to the emergency room, all patients must be questioned about their history of exposure, respiratory symptoms and body temperature. Those with suspected infection should be isolated immediately. The Polymerase Chain Reaction (PCR) test for COVID-19 should be carried out as soon as possible in all patients, taking the necessary preventive 
isolation measures until the result is obtained $[4,6]$. Patients should be operated in the shortest time possible. For those with a positive result in the diagnostic tests, respiratory parameters should be studied prior to surgery. To lessen the risk of cross-infection by COVID-19 in the perioperative period, isolated management and use of regulated operating rooms is recommended, to reduce their hospital stay as much as possible $[4,6,9,10]$.

So far, there seems to be no literature regarding hospital experience in Colombia with management of elderly patients with hip fracture during the current pandemic. This paper aims to describe the changes implemented in the care protocol of the Orthogeriatric Clinical Care Center of our Institution (Fundación Santa Fe de Bogotá [FSFB]) in relation to COVID-19 and how these have affected the management of patients in relation to pre-pandemic experience.

\section{Measures implemented in the hospital}

The Fundación Santa Fe de Bogotá (FSFB) is a university hospital of quaternary care located in the city of Bogotá, Colombia. It has an Orthogeriatric Clinical Care Center accredited by the Joint Commission International (JCI) and the AO Foundation in which a co-management model between Geriatric and Orthopedic services is carried out in patients 65 years or older who arrive at the emergency department and present with a hip fracture.

Since the report of the first case of COVID-19 in Colombia, the hospital's facilities have been restructured to divide the care of patients in emergency services, hospitalization floors, Intensive Care Units (ICU) and operating rooms into COVID-19 and NO COVID-19 zones. Upon admission to the hospital, all patients undergo a risk screening based on their clinical history and symptoms. Those patients with suspected infection (fever, respiratory symptoms, risk of exposure), or with infection previously confirmed by diagnostic test are immediately isolated and redirected to care in the COVID-19 area. Patients without suspicion of infection after the initial screening are attended in the NON COVID-19 area.

Patients who require hospitalization for hip fracture are requested upon admission to perform the PCR test for COVID-19. This test is a prerequisite for any surgical procedure in the hospital. By institutional guideline and based on international protocols, the PCR testing began to be performed in all patients in the FSFB hospital from May 2020. Before this, all the patients were considered suspicious of infection and were treated by the COVID-19 route. The use of face masks is always indicated for both the patient and the entire health team, regardless of the result of the diagnostic test.

In cases of relative emergencies (patients who require surgery within 24 or 48 hours after admission), a complete screening is done with a clinical history that specifically inquires risk factors for exposure to COVID-19; respiratory or gastrointestinal symptoms in the last 14 days; complete physical examination with emphasis on body temperature; pulmonary examination; and PCR test. Patients with a clinical history and physical examination free of suspicion and negative PCR are operated in the NON COVID-19 area of the operating rooms. If there are signs in the medical history or in the physical examination that qualify the patient as suspect of infection -even with a negative PCR test- the patient will be operated in the COVID-19 area. The same applies to those patients who have a positive PCR test. Patients with a positive PCR for COVID-19 are evaluated by the pulmonology service prior to performing surgery for analysis of respiratory parameters and stabilization of these if necessary.

\section{Methods}

A retrospective cohort's study was carried out in patients taken care of in the Orthogeriatric Clinical Care Center of the FSFB treated before and during the COVID-19 pandemic. The study was approved by the corporate research ethics committee of the FSFB University Hospital that are guided by The World Medical Association's (WMA) Declaration of Helsinki "as a statement of ethical principles for medical research involving human subjects, including research on identifiable human material and data" (WMA, 1964/2018).

For the group under study (patients admitted since the beginning of the COVID-19 pandemic), all patients in the Orthogeriatric Clinical Care Center between March 11, 2020, and March 11, 2021, were selected. The total sample obtained was 73 patients. For the control group, patients seen a year earlier during the same period (March 11, 2018 and March 11, 2019) were selected, for a total of 69 patients. The inclusion criteria were: patients 65 years or older, informed consent signed where they stated they agreed with the procedure and admission to the Orthogeriatric Clinical Care Center, diagnosis of hip fracture due to fragility or peri-prosthetic hip fracture confirmed by radiography. Exclusion criteria were: hip fracture secondary to polytrauma or high energy trauma, hip fracture that is associated with tumor or metastatic disease and hip fractures that were 7 days or older from the arrival to the emergency department.

Sociodemographic data was collected, including age, sex, Body Mass Index (BMI), fracture classification (according to AO Trauma and Vancouver classification) and Charlson Comorbidity Index (CCI). Within the clinical and surgical parameters, the Confusion Assessment Method (CAM) score, laboratories upon admission (hemoglobin, hematocrit, PTH, calcium, phosphorus, vitamin D levels), postoperative hemoglobin and hematocrit at 6 and 24 hours, type of surgical procedure, duration of the procedure and type of anesthesia were recorded; as well as the presence of respiratory symptoms, fever, and PCR test results in patients treated during the pandemic.

Inpatient complications -pressure ulcer, nosocomial pneumonia, Urinary Tract Infection (UTI), transfusional requirement, Admission to Intensive Care Unit (ICU), requirement of vasopressor support, surgical site infection, Acute Myocardial Infarction (AMI), Acute Kidney Injury failure (AKI), respiratory failure, cerebrovascular accident, Deep Vein Thrombosis (DVT) and Pulmonary thromboembolism (PE)-, and the main quality measures of the Orthogeriatric Clinical Care Center -time to surgery, delirium, length of hospital stay, in-hospital death, readmission at 30 days, death at 30 or 90 days- were also recorded.

\section{Data analysis}

An exploratory analysis of the variables was carried out by calculating proportions and frequencies for the discrete variables and measures of central tendency, dispersion, maximum and minimum for continuous variables. The Shapiro-Wilk test was applied as a normality test. To analyze differences between the two study groups, the proportions comparison test and the chi-square test were implemented, as well as the T test and the Mann-Whitney test to compare the continuous variables by period. All analyzes were performed with SPSS software v. 26.0 and Real Statistics v. 7.3 and values of $p<0.05$ were considered statistically significant. 
Citation: Olarte CM, López AM, Feldman JT, Zabala AL, Morales DC, et al. (2021) Hip Fracture Management in an Orthogeriatric Clinical Care Center during the Covid-19 Pandemic in Bogotá, Colombia. J Gerontol Geriatr Med 7: 117.

- Page 3 of 6 •

\section{Results}

The mean age of the group treated during the pandemic was 83.9 years $( \pm 0.9)$ and for patients attended before the pandemic was 81.7 years $( \pm 1)$. There was a predominance of women in both groups ( $71 \%$ pre-pandemic vs. $82.2 \%$ during the pandemic). No significant differences were found between the sociodemographic data of age, sex, BMI, and type of fracture. A significant difference was observed between the CCI scores, finding that $78.1 \%$ of the patients treated during the pandemic had a high level of comorbidity (score greater than or equal to 3) compared to $44.9 \%$ in those of the pre-pandemic period (CI 95\% 0.08, 0.49; $<<0.001$ ) (Table 1). No significant differences were found regarding clinical parameters.

\begin{tabular}{|c|c|c|c|c|}
\hline \multicolumn{5}{|c|}{ Sociodemographic data } \\
\hline Variable & $\begin{array}{c}\text { Pre - pandemic } \\
\quad(\mathrm{n}=69)\end{array}$ & $\begin{array}{l}\text { Pandemic pe- } \\
\quad \text { riod } \\
(n=73)\end{array}$ & $\mathbf{p}$ & $95 \%$ CI \\
\hline $\begin{array}{l}\text { Age (years) } \\
(\text { mean } \pm \text { SE) }\end{array}$ & $81.7 \pm 1$ & $83.9 \pm 0.9$ & 0.09 & $(-0.35,4.8)$ \\
\hline Sex (\%) & & & 0.164 & \\
\hline Male & $20(29 \%)$ & $13(17.8 \%)$ & & $(-0.35,0.29)$ \\
\hline Female & 49 (71\%) & $60(82.2 \%)$ & & $(-0.04,0.27)$ \\
\hline $\begin{array}{l}\text { Body mass index } \\
(\text { BMI) kg/m2) } \\
(\text { mean } \pm \text { SE) }\end{array}$ & $25 \pm 0.4$ & $23.9 \pm 0.5$ & 0.073 & $(-2.37,0.10)$ \\
\hline $\begin{array}{l}\text { Fracture classifi- } \\
\text { cation } \\
\text { (AO, Vancouver) } \\
\text { (\%) }\end{array}$ & & & 0.45 & \\
\hline 31-A1 & $13(18.8 \%)$ & $12(16.4 \%)$ & & $(-0.32,0.27)$ \\
\hline $31-\mathrm{A} 2$ & $17(24.6 \%)$ & $24(32.9 \%)$ & & $(-0.19,0.36)$ \\
\hline $31-\mathrm{A} 3$ & $8(11.6 \%)$ & $6(8.2 \%)$ & & $(-0.34,0.27)$ \\
\hline 31-B1 & $11(15.9 \%)$ & $9(12.3 \%)$ & & $(-0.34,0.26)$ \\
\hline 31-B2 & $11(15.9 \%)$ & $17(23.3 \%)$ & & $(-0.22,0.36)$ \\
\hline 31-B3 & $6(8.7 \%)$ & $1(1.4 \%)$ & & $(-0.39,0.24)$ \\
\hline Vancouver B & $2(2.9 \%)$ & $2(2.7 \%)$ & & $(-0.32,0.32)$ \\
\hline Vancouver C & $1(1.4 \%)$ & $2(2.7 \%)$ & & $(-0.31,0.33)$ \\
\hline $\begin{array}{l}\text { Charlson Co- } \\
\text { morbidity Index } \\
\text { (CCI) (\%) }\end{array}$ & & & $\begin{array}{l}<0.001 \\
*\end{array}$ & \\
\hline $\begin{array}{l}\text { No comorbidity } \\
\text { (0-1 points) }\end{array}$ & $24(34.8 \%)$ & $7(9.6 \%)$ & & $\begin{array}{l}(-0.59 \\
-0.006)\end{array}$ \\
\hline $\begin{array}{l}\text { Low comorbidity } \\
\text { ( } 2 \text { points) }\end{array}$ & $5(7.2 \%)$ & $7(9.6 \%)$ & & $(-0.31,0.34)$ \\
\hline $\begin{array}{l}\text { High comorbidity } \\
\text { (3 or more points) }\end{array}$ & $31(44.9 \%)$ & $57(78.1 \%)$ & & $(0.08,0.49)$ \\
\hline Missing data & $9(13 \%)$ & $2(2.7 \%)$ & & \\
\hline
\end{tabular}

Table 1: Sociodemographic data of patients seen before and during the pandemic.

$* \mathrm{SE}=$ standard error

*Highlighted p-values indicate statistically significant value.

Source: own work

Among the patients admitted during the pandemic, there were seven patients with symptoms associated with suspected COVID-19 infection (4 with respiratory symptoms and 3 patients with fever on admission), 61 patients underwent a PCR test on admission (83.5\%), and only one patient had a positive PCR result (Table 2).

\begin{tabular}{|c|c|c|c|c|}
\hline \multicolumn{5}{|c|}{ Clinical parameters } \\
\hline Variable & $\begin{array}{l}\text { Pre-pandemic } \\
\quad(\mathrm{n}=69)\end{array}$ & $\begin{array}{l}\text { Pandemic period } \\
\quad(n=73)\end{array}$ & $\mathbf{p}$ & $95 \% \mathrm{CI}$ \\
\hline $\begin{array}{c}\text { Preoperative } \\
\text { CAM scale (\%) }\end{array}$ & & & 0.596 & \\
\hline 0 & $53(76.8 \%)$ & $54(73.9 \%)$ & & $\begin{array}{c}(-0.21 \\
0.07)\end{array}$ \\
\hline 1 & $5(7.2 \%)$ & $6(8.2 \%)$ & & $\begin{array}{c}(-0.32, \\
0.33)\end{array}$ \\
\hline 2 & $2(2.8 \%)$ & $6(8.2 \%)$ & & $\begin{array}{c}(-0.28, \\
0.38)\end{array}$ \\
\hline 3 & $1(1.4 \%)$ & $2(2.7 \%)$ & & $\begin{array}{c}(-0.33, \\
0.35)\end{array}$ \\
\hline Missing data & $8(11.6)$ & $5(6.8)$ & & \\
\hline \multicolumn{5}{|l|}{$\begin{array}{c}\text { Respiratory } \\
\text { symptoms on } \\
\text { admission (\%) }\end{array}$} \\
\hline Yes & - & $6(8.2 \%)$ & & \\
\hline No & - & $67(91.8 \%)$ & & \\
\hline \multicolumn{5}{|l|}{$\begin{array}{c}\text { Fever on admis- } \\
\text { sion }(\%)\end{array}$} \\
\hline Yes & & $3(4.1 \%)$ & & \\
\hline No & & $70(95.9 \%)$ & & \\
\hline \multicolumn{5}{|l|}{$\begin{array}{c}\text { PCR for } \\
\text { COVID-19 (\%) }\end{array}$} \\
\hline Positive & & $1(1.4 \%)$ & & \\
\hline Negative & & $59(80.8 \%)$ & & \\
\hline No test & & $13(17.8 \%)$ & & \\
\hline $\begin{array}{c}\text { Preoperative He- } \\
\text { moglobin }(g / d L) \\
(\text { mean } \pm \text { ES })\end{array}$ & $13.7 \pm 0.2$ & $12.8 \pm 0.2$ & $0.013 *$ & $\begin{array}{l}(-1.51 \\
-0.18)\end{array}$ \\
\hline $\begin{array}{l}\text { Preoperative He- } \\
\text { matocrit }(\mathrm{g} / \mathrm{dL}) \\
(\text { mean } \pm \text { ES })\end{array}$ & $40.8 \pm 0.7$ & $38.9 \pm 0.7$ & 0.05 & $\begin{array}{c}(-3.86 \\
0.01)\end{array}$ \\
\hline $\begin{array}{c}\text { Hemoglobin } \\
6 \text { hours after } \\
\text { surgery }(g / d L) \\
(\text { mean } \pm \text { SE) }\end{array}$ & $11.4 \pm 0.2$ & $10.8 \pm 0.2$ & $0.043^{*}$ & $\begin{array}{l}(-1.24 \\
-0.02)\end{array}$ \\
\hline $\begin{array}{c}\text { Hematocrit } \\
6 \text { hours after } \\
\text { surgery }(g / d L) \\
(\text { mean } \pm \text { SE) }\end{array}$ & $33.9 \pm 0.6$ & $32.8 \pm 0.6$ & 0.201 & $\begin{array}{c}(-2.99 \\
0.64)\end{array}$ \\
\hline $\begin{array}{c}\text { Hemoglobin } \\
24 \text { hours after } \\
\text { surgery }(\mathrm{g} / \mathrm{dL}) \\
(\text { mean } \pm \mathrm{SE})\end{array}$ & $14.4 \pm 2.2$ & $10.1 \pm 0.2$ & 0.059 & $\begin{array}{c}(-8.78 \\
0.18)\end{array}$ \\
\hline $\begin{array}{c}\text { Hematocrit } \\
24 \text { hours after } \\
\text { surgery }(g / d L) \\
(\text { mean } \pm \text { SE) }\end{array}$ & $34.1 \pm 1.8$ & $30.6 \pm 0.7$ & 0.077 & $\begin{array}{c}(-7.35 \\
0.39)\end{array}$ \\
\hline
\end{tabular}

Table 2: Clinical parameters of patients seen before and during the pandemic.

$* \mathrm{SE}=$ standard error

*Highlighted p-values indicate statistically significant value.

Source: own work

Regarding surgical information, there was a statistically significant difference in the type of anesthesia used, with a predominance of general anesthesia in the pre-pandemic group and regional anesthesia 
Citation: Olarte CM, López AM, Feldman JT, Zabala AL, Morales DC, et al. (2021) Hip Fracture Management in an Orthogeriatric Clinical Care Center during the Covid-19 Pandemic in Bogotá, Colombia. J Gerontol Geriatr Med 7: 117.

in the pandemic group (CI 95\% $-0.52,-0.05 ; \mathrm{p}<0.001)$ (Table 3). The average duration of surgery between the pre-pandemic and pandemic group was $87.8( \pm 4.8)$ minutes and $103.9( \pm 4.7)$ minutes, respectively, with a statistically significant difference (CI 95\% 2.81, 29.2; $\mathrm{p}=0.017$ ).

\begin{tabular}{|c|c|c|c|c|}
\hline \multicolumn{5}{|c|}{ Surgical information } \\
\hline Variable & $\begin{array}{c}\text { Pre-pandemic } \\
(\mathbf{n}=\mathbf{6 9})\end{array}$ & $\begin{array}{c}\text { Pandemic } \\
\text { riod } \\
(\mathbf{n}=\mathbf{7 3})\end{array}$ & $\mathbf{p e -}$ & $\mathbf{9 5 \%} \mathbf{~ C I}$ \\
\hline Procedure (\%) & & & 0.278 & \\
\hline Arthroplasty & $19(27.5 \%)$ & $21(28.8 \%)$ & & $(-0.26,0.29)$ \\
\hline $\begin{array}{c}\text { Open reduction with } \\
\text { internal fixation }\end{array}$ & $28(40.6 \%)$ & $37(50.7 \%)$ & & $(-0.14,0.34)$ \\
\hline $\begin{array}{c}\text { Closed reduction } \\
\text { with internal fixation }\end{array}$ & $22(31.9 \%)$ & $15(20.5 \%)$ & & $(-0.39,0.16)$ \\
\hline $\begin{array}{c}\text { Length of the pro- } \\
\text { cedure (minutes) } \\
\text { (mean } \pm \text { SE) }\end{array}$ & $87.8 \pm 4.8$ & $103.9 \pm 4.7$ & $0.017 *$ & $(2.81,29.2)$ \\
\hline Type of anesthesia & $44(63.7 \%)$ & $26(35.6 \%)$ & & $(-0.52,-0.05)$ \\
\hline General & $19(27.5 \%)$ & $25(34.2 \%)$ & & $(-0.21,0.33)$ \\
\hline Spinal & $3(4.3 \%)$ & $22(30.1 \%)$ & & $(-0.04,0.55)$ \\
\hline Regional & $3(2.8 \%)$ & $0(0.0 \%)$ & & \\
\hline Local assisted & $1(1.4)$ & & & \\
\hline Missing data & & $<0.001^{*}$ & \\
\hline
\end{tabular}

Table 3: Surgical information of patients seen before and during the pandemic.

$* \mathrm{SE}=$ standard error

*Highlighted p-values indicate statistically significant value

Source: own work

As for hospital complications, a higher number of patients seen during the pandemic presented urinary tract infection and required transfusion of packed red blood cells (Table 4).

Among the quality measures of the Orthogeriatric Clinical Care Center, it was found that the average time from admission until the beginning of surgery was $29.8( \pm 4.9)$ hours in the pre-pandemic group and $36( \pm 1.7)$ hours in the pandemic group, with a statistically significant difference (CI 95\% 1.13, 11.2; $\mathrm{p}=0.017$ ). As well, the length of hospitalization averaged $5.3( \pm 0.3)$ days in the first group and $5.5( \pm 0.4)$ in the second group in which there was no statistical significant difference. There were no statistically significant differences regarding hospital delirium, in-hospital death, readmission at 30 days, and death at 30 and 90 days (Table 5).

\section{Discussion}

Fragility hip fractures in patients 65 years or older have a great impact on life quality, functionality and mortality during the first year after the event [11]. Studies have shown that half of these patients do not regain their pre-fracture mobility, and have in-hospital mortality figures of $7 \%, 30$ day mortality between $5 \%$ and $10 \%$ and $20 \%$ to $30 \%$ mortality one year after the procedure [12-14]. Because of this, specialized care in geriatric patients with hip fracture is necessary.

The implementation of orthogeriatric centers for the treatment of patients with fragility hip fractures has had a favorable impact in terms of reducing morbidity and mortality. Henderson et al., found

\begin{tabular}{|c|c|c|c|c|}
\hline \multicolumn{5}{|c|}{ In-hospital complications } \\
\hline Variable & $\begin{array}{l}\text { Pre-pandemic } \\
\quad(n=69)\end{array}$ & $\begin{array}{c}\text { Pandemic } \\
\text { period } \\
(n=73)\end{array}$ & $\mathbf{p}$ & $95 \% \mathrm{CI}$ \\
\hline Pressure ulcer & $3(4.3 \%)$ & $10(13.7 \%)$ & 0.079 & $\begin{array}{l}(0.91, \\
13.2)\end{array}$ \\
\hline $\begin{array}{l}\text { Nosocomial pneu- } \\
\text { monia }\end{array}$ & $1(1.4 \%)$ & $1(1.4 \%)$ & 1.000 & $\begin{array}{l}(0.05 \\
15.4)\end{array}$ \\
\hline $\begin{array}{l}\text { Urinary tract } \\
\text { infection }\end{array}$ & $2(2.9 \%)$ & $9(12.3 \%)$ & 0.056 & $\begin{array}{l}(0.98 \\
22.6)\end{array}$ \\
\hline $\begin{array}{c}\text { Transfusion require- } \\
\text { ment }\end{array}$ & $24(34.8 \%)$ & $35(47.9 \%)$ & 0.127 & $\begin{array}{c}(-0.12 \\
0.38)\end{array}$ \\
\hline $\begin{array}{c}\text { Intensive care unit } \\
\text { admission }\end{array}$ & $18(26.1 \%)$ & $14(19.2 \%)$ & 0.422 & $\begin{array}{l}(0.30 \\
1.48)\end{array}$ \\
\hline $\begin{array}{c}\text { Vasopressor require- } \\
\text { ment }\end{array}$ & $11(15.9 \%)$ & $14(19.2 \%)$ & 0.664 & $\begin{array}{l}(0.52 \\
2.98)\end{array}$ \\
\hline $\begin{array}{l}\text { Surgical site } \\
\text { infection }\end{array}$ & $0(0.0 \%)$ & $0(0.0 \%)$ & & \\
\hline $\begin{array}{l}\text { Acute myocardial } \\
\text { infarction }\end{array}$ & $1(1.4 \%)$ & $1(1.4 \%)$ & 1.000 & $\begin{array}{l}(0.05 \\
15.4)\end{array}$ \\
\hline Acute kidney injury & $3(4.3 \%)$ & $0(0.0 \%)$ & 0.112 & \\
\hline Respiratory failure & $2(2.9 \%)$ & $2(2.7 \%)$ & 1.000 & $\begin{array}{l}(0.12 \\
6.89)\end{array}$ \\
\hline $\begin{array}{l}\text { Deep vein throm- } \\
\text { bosis }\end{array}$ & $1(1.4 \%)$ & $0(0.0 \%)$ & 0.486 & \\
\hline $\begin{array}{c}\text { Pulmonary throm- } \\
\text { boembolism }\end{array}$ & $1(1.4 \%)$ & $3(4.1 \%)$ & 0.62 & $\begin{array}{l}(0.29 \\
28.7)\end{array}$ \\
\hline
\end{tabular}

Table 4: In-hospital complications of patients treated before and during the pandemic.

$* \mathrm{SE}=$ standard error

*Highlighted p-values indicate statistically significant value.

Source: own work

\begin{tabular}{|c|c|c|c|c|}
\hline \multicolumn{5}{|c|}{ Quality indicators of the Orthogeriatric Program } \\
\hline Variable & $\begin{array}{c}\text { P r e - p a n - } \\
\text { demic } \\
(\mathbf{n}=\mathbf{6 9})\end{array}$ & $\begin{array}{c}\text { Pa n d e mic } \\
\text { period } \\
(\mathbf{n}=73)\end{array}$ & $\mathbf{p}$ & $\mathbf{9 5 \%}$ CI \\
\hline $\begin{array}{c}\text { Time from admission until } \\
\text { surgery (hours) (mean } \pm \\
\text { SE) }\end{array}$ & $29.8 \pm 4.9$ & $36 \pm 1.7$ & $0.017 *$ & $(1.13,11.2)$ \\
\hline In-hospital delirium (\%) & $11(15.9 \%)$ & $13(17.8 \%)$ & 0.825 & $(0.47,2.75)$ \\
\hline $\begin{array}{c}\text { Length of stay (days) (mean } \\
\pm \text { SE) }\end{array}$ & $5.3( \pm 0.3)$ & $5.5( \pm 0.4)$ & 0.781 & $(-0.81,1.07)$ \\
\hline In-hospital death & $1(1.4 \%)$ & $2(2.7 \%)$ & 1.000 & $(0.17,21.6)$ \\
\hline Readmission within 30 days & $8(11.6 \%)$ & $8(11 \%)$ & 1.000 & $(0.33,2.65)$ \\
\hline 30-Day Mortality & $4(5.8 \%)$ & $2(2.7 \%)$ & 0.432 & $(0.08,2.58)$ \\
\hline 90-Day Mortality & $4(5.8 \%)$ & $8(11 \%)$ & 0.369 & $(0.57,6.97)$ \\
\hline
\end{tabular}

Table 5: Quality indicators of the orthogeriatric program of patients treated before and during the pandemic.

$* \mathrm{SE}=$ standard error

*Highlighted p-values indicate statistically significant value.

Source: own work

that after a joint management between orthopedics and geriatrics in elderly patients with hip fracture, there was a significant decrease in annual mortality, from $19 \%$ with standard orthopedic management 
to $9.7 \%$ after establishing an orthogeriatric service; as well as a decrease in in-hospital mortality and length of hospitalization [15]. At the FSFB University Hospital, there is a co-management program between orthopedics and geriatrics for all patients 65 years or older who present with a fragility hip fracture, which follows a specific management protocol with the aim of reducing the time from admission to surgery, complications and hospital stay to reduce functional dependence, morbidity, as well as short - and long-term mortality.

In this study, the sociodemographic, clinical characteristics and outcomes of surgical management of patients 65 years or older with hip fracture treated during the COVID-19 pandemic by an Orthogeriatric Clinical Care Center were collected and compared with a group of patients with similar characteristics attended by the same center prior to the COVID-19 pandemic. Within the group treated during the pandemic, a PCR test for COVID-19 was performed on 59 of the 73 patients, in which only one patient had a positive result. The 13 patients not tested were treated at the beginning of the pandemic when the PCR test was not fully available in our institution and wasn't required for surgical procedures. A CCI indicative of high comorbidity ( 3 or more points) was found in $78.1 \%$ of the cases treated during the pandemic compared to $44.9 \%$ of patients in the pre-pandemic group (CI 95\% 0.08, 0.49; $\mathrm{p}<0.001$ ). The aforementioned shows a greater burden of morbidity and risk of mortality in the group admitted during the pandemic. There was a significant decrease in the implementation of general anesthesia and increased use of spinal and regional anesthesia during surgery in the pandemic group in contrast to the previous period (CI 95\% $-0.52,-0.05 ; \mathrm{p}<0.001$ ). Endotracheal intubation is a high-risk procedure for exposure and transmission of the virus due to the high load of the virus found in respiratory secretions [16], which justifies the change in anesthetic behavior.

The average time from admission to surgery was 29.8 hours and 36 hours before and during the pandemic, respectively, with a statistically significant difference (CI 95\% 1.13, 11.2; $\mathrm{p}=0.017$ ). The increase in time between one period and the other can be associated with the protective and diagnostic measures added to the management protocol in relation to COVID-19. However, it should be noted that both groups still present times below 48 hours, which is associated with a lower risk of nosocomial complications and mortality in these patients [7] and is one of our Orthogeriatric Clinical Care Center goals. It was also found that the mean duration of surgery in patients managed during the pandemic (103.9 \pm 4.7 minutes) was significantly higher when compared to the pre pandemic group $(87.8 \pm 4.8$ minutes) (CI $95 \%$ $2.81,29.2 ; \mathrm{p}=0.017)$. At the beginning of the pandemic, all patients admitted with a hip fragility fracture were taken to the operating room without a RT-PCR screening test.

Therefore, all the operating room personnel had to comply with strict safety measures such as the use of a surgical scrub suit, isolation suit, disposable surgical gown, three disposable latex surgical gloves, disposable fitted N-95, face-shield and eyewear protection during the procedure. These safety measures made it difficult for the surgery team to perform the same way as when operating in normal conditions. As the PCR test was introduced at the FSFB, all patients admitted to the hospital who needed to undergo a surgical procedure had to have a test result. Depending on the result, the use of intraoperative security measures were established as mentioned before.

The cohort of patients seen during the pandemic presented more cases of UTI and had a higher postoperative transfusional requirement. The latter may be associated with the greater burden of comorbidities and the longer duration of the surgical procedure found in this cohort. No statistically significant difference was found regarding ICU admission, incidence of delirium, length of hospitalization, in-hospital mortality or readmission. In terms of early mortality after hip fracture surgery in patients with diagnosed COVID-19, a systematic review by Wang et al., found that there was a $32.6 \%$ death rate in patients with COVID-19 and concomitant hip fracture surgery [17]. Additionally, they found that patients that did not have a diagnosis of COVID-19 compared to those who did, had a relative risk ratio for early mortality of $5.66(95 \%$ IC $4.01,7.98 ; p<0.001) 17$. In the present study, no statistically significant differences were found for mortality at 30 days and 90 days after the procedure between both groups.

Despite having just one patient with a positive test result for COVID-19, it was considered of great importance to be able to determine whether the infection prevention measures integrated into the management algorithm of patients could have any impact on their main outcomes, which did not happen. The main weakness of this study was the small size of the sample collected. Thus, it is important that similar studies are carried out with larger samples to establish stronger associations for the outcomes of this vulnerable population.

\section{Conclusion}

In conclusion, even though patients of 65 years or older who arrived at the emergency department with a hip fracture during the pandemic were more comorbid -which gives them a greater potential for complication- and had to comply with the measures added to the treatment algorithm of the orthogeriatric program in relation to COVID-19, it is possible to uphold the management path that these patients require, which has a positive effect on their clinical outcomes. This makes evident the significant benefit of co-management between orthopedics and geriatrics through standardized protocols in this patient population.

\section{Funding Acknowledgment}

This research received no specific grant from any funding agency in the public, commercial, or not-for-profit sectors.

\section{Declaration of Conflicting Interests}

All authors declare that there is no conflict of interest.

\section{References}

1. Zhu N, Zhang D, Wang W, Li X, Yang B, et al. (2020) A novel coronavirus from patients with pneumonia in China, 2019. N Engl J Med 382: 727-733.

2. World Health Organization (WHO) (2020) WHO Director-General's opening remarks at the media briefing on COVID-19 - 11 March 2020. WHO, Geneva, Switzerland.

3. Sanders JM, Monogue ML, Jodlowski TZ, Cutrell JB (2020) Pharmacologic Treatments for Coronavirus Disease 2019 (COVID-19): A Review. JAMA 323: 1824-1836.

4. Liu J, Mi B, Hu L, Xiong Y, Xue H, et al. (2020) Preventive strategy for the clinical treatment of hip fractures in the elderly during the COVID-19 outbreak: Wuhan's experience. Aging (Albany NY) 12: 7619-7625.

5. Ministerio de Salud y Protección Social (2020) Colombia confirma su primer caso de COVID-19. Boletín de Prensa (Vol-50).

6. Upadhyaya GK, Iyengar K, Jain VK, Vaishya R (2020) Challenges and strategies in management of osteoporosis and fragility fracture care during COVID-19 pandemic. J Orthop 21: 287-290. 
Citation: Olarte CM, López AM, Feldman JT, Zabala AL, Morales DC, et al. (2021) Hip Fracture Management in an Orthogeriatric Clinical Care Center during the Covid-19 Pandemic in Bogotá, Colombia. J Gerontol Geriatr Med 7: 117.

7. Simunovic N, Devereaux PJ, Sprague S, Guyatt GH, Schemitsch E, et al. (2010) Effect of early surgery after hip fracture on mortality and complications: Systematic review and meta-analysis. CMAJ 182: 1609-1616.

8. Berlin DA, Gulick RM, Martinez FJ (2020) Severe Covid-19. N Engl J Med 383: 2451-2560.

9. Cheung ZB, Forsh DA (2020) Early outcomes after hip fracture surgery in COVID-19 patients in New York City. J Orthop 21: 291-296.

10. Gómez-Barrena E, Rubio-Suárez JC, Fernández-Baillo $\mathrm{N}$, Antuña $\mathrm{S}$, Cruz-Pardos A, et al. (2020) Limiting spread of COVID-19 in an orthopaedic department-a perspective from Spain. J Surg Case Rep 2020: rjaa095.

11. Mauck KF, Clarke BL (2006) Diagnosis, Screening, Prevention, and Treatment of Osteoporosis. Mayo Clin Proc 81: 662-672.

12. Castronuovo E, Pezzotti P, Franzo A, Di Lallo D, Guasticchi G (2011) Early and late mortality in elderly patients after hip fracture: a cohort study using administrative health databases in the Lazio region, Italy. BMC Geriatr 11:37.
13. Sheehan KJ, Sobolev B, Guy P (2017) Mortality by Timing of Hip Fracture Surgery: Factors and Relationships at Play. J Bone Joint Surg Am 99: 106.

14. Doshi HK, Ramason R, Azellarasi J, Naidu G, Chan WL (2014) Orthogeriatric model for hip fracture patients in Singapore: our early experience and initial outcomes. Arch Orthop Trauma Surg 134: 351-357.

15. Henderson CY, Shanahan E, Butler A, Lenehan B, O'Connor M, et al. (2017) Dedicated orthogeriatric service reduces hip fracture mortality. Ir J Med Sci 186: 179-184.

16. Weissman DN, de Perio MA, Radonovich LJ Jr (2020) COVID-19 and Risks Posed to Personnel During Endotracheal Intubation. JAMA 323: 2027-2028.

17. Wang KC, Xiao R, Cheung ZB, Barbera JP, Forsh DA (2020) Early mortality after hip fracture surgery in COVID-19 patients: A systematic review and meta-analysis. J Orthop 22: 584-591. 


\section{H}

Advances In Industrial Biotechnology | ISSN: 2639-5665

Advances In Microbiology Research | ISSN: 2689-694X

Archives Of Surgery And Surgical Education | ISSN: 2689-3126

Archives Of Urology

Archives Of Zoological Studies | ISSN: 2640-7779

Current Trends Medical And Biological Engineering

International Journal Of Case Reports And Therapeutic Studies | ISSN: 2689-310X

Journal Of Addiction \& Addictive Disorders | ISSN: 2578-7276

Journal Of Agronomy \& Agricultural Science | ISSN: 2689-8292

Journal Of AIDS Clinical Research \& STDs | ISSN: 2572-7370

Journal Of Alcoholism Drug Abuse \& Substance Dependence | ISSN: 2572-9594

Journal Of Allergy Disorders \& Therapy | ISSN: 2470-749X

Journal Of Alternative Complementary \& Integrative Medicine | ISSN: 2470-7562

Journal Of Alzheimers \& Neurodegenerative Diseases | ISSN: 2572-9608

Journal Of Anesthesia \& Clinical Care | ISSN: 2378-8879

Journal Of Angiology \& Vascular Surgery | ISSN: 2572-7397

Journal Of Animal Research \& Veterinary Science | ISSN: 2639-375

Journal Of Aquaculture \& Fisheries | ISSN: 2576-5523

Journal Of Atmospheric \& Earth Sciences | ISSN: 2689-8780

Journal Of Biotech Research \& Biochemistry

Journal Of Brain \& Neuroscience Research

Journal Of Cancer Biology \& Treatment | ISSN: 2470-7546

Journal Of Cardiology Study \& Research | ISSN: 2640-768X

Journal Of Cell Biology \& Cell Metabolism | ISSN: 2381-1943

Journal Of Clinical Dermatology \& Therapy | ISSN: 2378-8771

Journal Of Clinical Immunology \& Immunotherapy | ISSN: 2378-8844

Journal Of Clinical Studies \& Medical Case Reports | ISSN: 2378-880

Journal Of Community Medicine \& Public Health Care | ISSN: 2381-1978

Journal Of Cytology \& Tissue Biology | ISSN: 2378-9107

Journal Of Dairy Research \& Technology | ISSN: 2688-9315

Journal Of Dentistry Oral Health \& Cosmesis | ISSN: 2473-6783

Journal Of Diabetes \& Metabolic Disorders | ISSN: 2381-201X

Journal Of Emergency Medicine Trauma \& Surgical Care | ISSN: 2378-8798

Journal Of Environmental Science Current Research | ISSN: 2643-5020

Journal Of Food Science \& Nutrition | ISSN: 2470-1076

Journal Of Forensic Legal \& Investigative Sciences | ISSN: 2473-733X

Journal Of Gastroenterology \& Hepatology Research | ISSN: 2574-2566
Journal Of Genetics \& Genomic Sciences | ISSN: 2574-2485

Journal Of Gerontology \& Geriatric Medicine | ISSN: 2381-8662

Journal Of Hematology Blood Transfusion \& Disorders | ISSN: 2572-2999

Journal Of Hospice \& Palliative Medical Care

Journal Of Human Endocrinology | ISSN: 2572-9640

Journal Of Infectious \& Non Infectious Diseases | ISSN: 2381-8654

Journal Of Internal Medicine \& Primary Healthcare | ISSN: 2574-2493

Journal Of Light \& Laser Current Trends

Journal Of Medicine Study \& Research | ISSN: 2639-5657

Journal Of Modern Chemical Sciences

Journal Of Nanotechnology Nanomedicine \& Nanobiotechnology | ISSN: 2381-2044

Journal Of Neonatology \& Clinical Pediatrics | ISSN: 2378-878X

Journal Of Nephrology \& Renal Therapy | ISSN: 2473-7313

Journal Of Non Invasive Vascular Investigation | ISSN: 2572-7400

Journal Of Nuclear Medicine Radiology \& Radiation Therapy | ISSN: 2572-7419

Journal Of Obesity \& Weight Loss | ISSN: 2473-7372

Journal Of Ophthalmology \& Clinical Research | ISSN: 2378-8887

Journal Of Orthopedic Research \& Physiotherapy | ISSN: 2381-2052

Journal Of Otolaryngology Head \& Neck Surgery | ISSN: 2573-010X

Journal Of Pathology Clinical \& Medical Research

Journal Of Pharmacology Pharmaceutics \& Pharmacovigilance | ISSN: 2639-5649

Journal Of Physical Medicine Rehabilitation \& Disabilities | ISSN: 2381-8670

Journal Of Plant Science Current Research | ISSN: 2639-3743

Journal Of Practical \& Professional Nursing | ISSN: 2639-568

Journal Of Protein Research \& Bioinformatics

Journal Of Psychiatry Depression \& Anxiety | ISSN: 2573-0150

Journal Of Pulmonary Medicine \& Respiratory Research | ISSN: 2573-0177

Journal Of Reproductive Medicine Gynaecology \& Obstetrics | ISSN: 2574-2574

Journal Of Stem Cells Research Development \& Therapy | ISSN: 2381-2060

Journal Of Surgery Current Trends \& Innovations | ISSN: 2578-7284

Journal Of Toxicology Current Research | ISSN: 2639-3735

Journal Of Translational Science And Research

Journal Of Vaccines Research \& Vaccination | ISSN: 2573-0193

Journal Of Virology \& Antivirals

Sports Medicine And Injury Care Journal | ISSN: 2689-8829

Trends In Anatomy \& Physiology | ISSN: 2640-7752

Submit Your Manuscript: https://www.heraldopenaccess.us/submit-manuscript 